\title{
PEMANFAATAN EKSTRAK DAUN MAHKOTA DEWA (Phaleria macrocarpa (Scheff.) Boerl) SEBAGAI PENGAWET TOMAT
}

\author{
The Utilization of Phaleria macrocarpa (Scheff.) Boerl Leaf Extract as \\ Preservatives for Tomato
}

*Dina Supriatni, Irwan Said, dan Siang Tandi Gonggo

Pendidikan Kimia/FKIP - Universitas Tadulako, Palu - Indonesia 94118

Received 07 March 2016, Revised 07 April 2016, Accepted 06 May2016

\begin{abstract}
Tomato fruit is one of the fruits susceptible to decay because of its high water content. The durability of tomato can be improved by storing in a humid place or by adding of a preservative. Phaleriamacrocarpa (Scheff.) Boerlleaf can act as an antibacterial due to thesaponin compounds contained therein. This study aimed to investigate the phaleriamacrocarpa (Scheff.) Boerlleaf extract as a preservative for tomatoes, and to determine the concentration of leaf extract to sustain tomatoes texture longer. The method used in this study was the maceration for extraction, and iodometric titration to determine of vitamin $C$ levels before and after curing. The results showed that the pickling tomatoes using phaleriamacrocarpa (Scheff.) Boerl leaf extract with a concentration of $6 \%$ sustained tomatoes up to 9 days, and the fruit decreased levels of vitamin C from $33.440 \mathrm{mg} / 100 \mathrm{~g}$ material into $27.580 \mathrm{mg} / 100 \mathrm{~g}$ of material.
\end{abstract}

Keywords: Phaleriamacrocarpa (Scheff.) Boerl., Preservation, Tomatoes, and levels of Vitamin C.

\section{Pendahuluan}

Bahan pangan merupakan kebutuhan pokok bagi manusia yang akan terus meningkat sesuai dengan laju pertumbuhan penduduk. Namun, bahan pangan akan mengalami perubahan-perubahan yang tidak diinginkan seperti pembusukan dan ketengikan. Proses pembusukan dan ketengikan disebabkan oleh adanya reaksi kimia yang bersumber dari dalam dan luar bahan pangan tersebut(Barus, 2009).

Pangan mudah mengalami kerusakan secara fisik, mekanis, mikrobiologis, biologis, dan kimia karena adanya karbohidrat, protein, lemak, air, vitamin, dan mineral yang terkandung di dalamnya. Oleh karena itu, upaya pengawetan pangan perlu dilakukan untuk mempertahankan sifat fisik dan kimia pangan serta meningkatkan daya simpan agar lebih lama (Pristiadi, 2012).

Buah tomat bisa langsung dikonsumsi dalam keadaan segar ataupun dibuat jus. Bentuk buahnya yang bulat dengan warna merah serta rasanya yang manis-manis asam merupakan daya tarik tersendiri yang tidak dimiliki oleh buah lainnya. Buah tomat

*Correspondence:

Dina Supriatni

Program Studi Pendidikan Kimia, Fakultas Keguruan dan

Ilmu Pendidikan, Universitas Tadulako

email: dinasupriatni@gmail.com

Published by Universitas Tadulako 2016 mudah untuk ditanam dan bersifat responsif terhadap berbagai perlakuan eksperimen dan sangat berpotensi untuk dikomersialkan baik di dalam maupun luar negeri. Namun, tomat juga merupakan salah satu buah yang cepat mengalami pembusukan(Trisnawati, dkk., 2003).

Pembusukan bahan makanan terjadi karena adanya pengaruh bakteri pembusuk. Pembusukan lebih sering terjadi pada bahan makanan yang basah dan lembab. Hal ini terjadi karena kadar air yang tinggi dalam makanan dapat mempercepat proses pembusukan. Buah tomat dapat mengalami pembusukan setelah dibiarkan selama 5 hari(Purwadi, dkk., 2007).

Daya tahan buah tomat dapat ditingkatkan dengan menyimpannya ditempat yang lembab ataupun melalui pemberian pengawet. Pengawet ada dua yaitu pengawet sintesis dan pengawet alami yang berfungsi membantu dan mempertahankan bahan makanan dari serangan mikroorganisme pembusuk bakteri dengan cara menghambat, mencegah, menghentikan proses pembusukan, fermentasi, pengasaman atau kerusakan komponen lain dari bahan pangan(Adawiyah, dkk., 1998). Saat ini penggunaan bahan pengawet sintetis tidak direkomendasikan oleh Badan Pengawas Obat dan Makanan (BPOM) karena 
diduga dapat menimbulkan penyakit kanker (carcinogen agent). Karena itu perlu dicari alternatif lain yaitu bahan pengawet alami yang bersumber dari bahan alam. Bahan pengawet alami ini hampir terdapat pada semua tumbuhtumbuhan dan buah-buahan tersebar diseluruh tanah air(Barus, 2009).

Pengawet alami yang berasal dari tumbuhan memiliki keunggulan dibandingkan dengan pengawet sintesis. Pengawet alami dapat mempertahankan bahan makanan dengan biaya yang relatif murah dan ramah lingkungan (Adelaku, 2014).

Zat aktif yang terkandung dalam berbagai jenis ekstrak tumbuhan diketahui dapat menghambat beberapa mikroba patogen maupun perusak makanan. Zat aktif tersebut dapat berasal dari bagian tumbuhan seperti biji, buah, rimpang, batang, daun, dan umbi. Sebagai contoh daun mahkota dewa(Koswara, 2009).

Berdasarkan penelitian ilmiah yang telah dilakukan, diketahui bahwa senyawa 2,6,4'-Trihidroksi-4-Metoksi Benzofenon dari ekstrak metanol, n-heksan, kloroform dan etil asetat daun mahkota dewa mampu berperan sebagai antioksidan(Susilawati., dkk., 2011).Daun mahkota dewa mengandung alkaloid, saponin serta polifenol. Senyawa saponin merupakan larutan berbuih yang diklasifikasikan berdasarkan struktur aglycon ke dalam triterpenoid dan steroid saponin. Senyawa saponin mampu berperan sebagai pengawet alami karena dapat bekerja sebagai antimikroba yang akan merusak membran sitoplasma(Gotawa, dkk., 1999).

Saponinterdiri dari sapogenin yang merupakan molekul aglikon dan sebuah gula. Saponin merupakan senyawa yang menimbulkan busa jika dikocok dalam air dan pada konsentrasi rendah sering menyebabkan hemolisis sel darah merah (Hudaya, dkk., 2013). Reaksi hidrolisis saponin dalam air tertera pada Gambar 1.

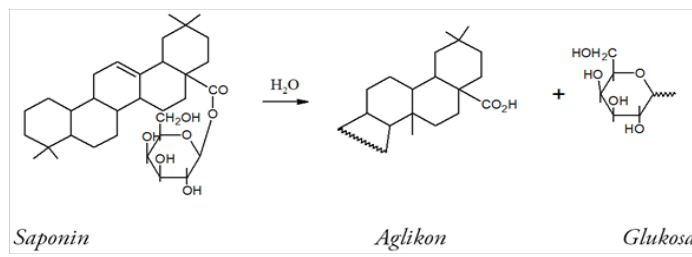

Gambar 1. Reaksi Hidrolisis Saponin dalam Air

Tujuan dalam mengkonsumsi buah adalah untuk memperoleh vitamin yang tentunya dibutuhkan oleh tubuh untuk reaksi metabolisme dalam sel. Kadar vitamin C pada buah tomat adalah $40 \mathrm{mg} / 100 \mathrm{~g}$ (Trisnawati, dkk., 2003). Tulisan ini bertujuan untuk menginvestigasi ekstrak daun mahkota dewa dalam mempertahankan tekstur dan kandungan vitamin $\mathrm{C}$ yang terkandung di dalamnya.

\section{Metode}

\section{Alat dan Bahan}

Peralatan yang digunakan pada penelitian ini adalah blender, baskom, tabung reaksi, neraca digital, rak tabung reaksi, alumunium foil, erlenmeyer $1000 \mathrm{~mL}$, shaker, gelas ukur $250 \mathrm{~mL}$ dan $10 \mathrm{~mL}$, labu ukur $100 \mathrm{~mL}$, pipet tetes, corong, kertas saring, vacuum pump, rotary evaporator, botol kecil, keranjang kecil, spatula, batang pengaduk, buret $25 \mathrm{~mL}$, klem dan statif, serta gelas kimia $100 \mathrm{~mL}$ dan 1000 $\mathrm{mL}$. Sedangkan bahan yang digunakan adalah daun mahkota dewa, buah tomat yang berasal dari pasar Inpres Palu Barat, metanol (Merck), larutan $\mathrm{HCl} 2 \mathrm{~N}$ (J.T Baker), larutan amilum $1 \%$ (Merck), larutan standar iodine 0,01 N (Ajax chemicals), dan aquades.

\section{Cara Kerja}

Proses pembuatan ekstrak daun mahkota dewa dilakukan dengan cara mencuci daun yang telah dipetik hingga bersih dan dikeringkan selama 15 hari. Kemudian, daun tersebut dihaluskan dengan menggunakan blender dan ditimbang sebanyak 100 gram. Selanjutnya, melakukan uji busa saponin dengan cara memasukkan 0,5 gram simplisia ke dalam tabung reaksi yang telah berisikan $10 \mathrm{~mL}$ aquades, mengocoknya, dan menambahkan 1 tetes larutan $\mathrm{HCl} 2 \mathrm{~N}$ (Suharto, dkk., 2012). Setelah itu, dilakukan maserasi selama 3 x 24 jam dengan menambahkan $600 \mathrm{~mL}$ metanol. Kemudian, ekstrak dikonsentrasikan dengan menggunakan rotary evaporator pada suhu 50oC dengan kecepatan $8 \mathrm{rpm}$. Setelah diperoleh ekstrak kental, kemudian dilakukan uji busa saponin kembali. Setelah itu, membuat larutan ekstrak dengan konstrasi $0 \%, 2 \%, 4 \%$, dan $6 \%$.

Pengawetan buah tomat dilakukan dengan cara mencelup buah tomat ke dalam larutan ekstrak selama 5 detik dan dibiarkan selama beberapa hari. Parameter yang diamati adalah perubahan warna, bau, tekstur, dan kadar vitamin $\mathrm{C}$ sebelum dan sesudah pengawetan. Penentuan kadar vitamin C dilakukan dengan cara menimbang 100 gram buah tomat dan menghaluskannya dengan menggunakan blender. Selanjutnya, mengambil 20 gram sluri dan mengencerkannya hingga $100 \mathrm{~mL}$. 
Kemudian, menyaring larutan sluri hingga diperoleh filtrat buah tomat. Selanjutnya, memasukkan $25 \mathrm{~mL}$ filtrat, $20 \mathrm{~mL}$ aquades, dan $2 \mathrm{~mL}$ amilum $1 \%$ ke dalam erlenmeyer. Setelah itu, melakukan titrasi dengan menggunakan larutan standar iodin $0,01 \mathrm{~N}$ sebagai titrannya (Muarfah, 2008).

\section{Hasil dan Pembahasan}

Penelitian ini dilakukan untuk membuktikan apakah ekstrak daun mahkota dewa dapat dijadikan sebagai pengawet tomat dan menentukan konsentrasi ekstrak daun mahkota dewa yang dapat mempertahankan tomat lebih lama. Metode yang digunakan dalam penelitian ini adalah maserasi untuk pembuatan ekstrak dan titrasi iodometri untuk menentukan kadar vitamin C sebelum dan sesudah pengawetan.

\section{Kadar Vitamin C pada Buah Tomat}

Ekstrak daun mahkota dewa (Phaleria macrocarpa (Scheff.) Boerl) yang dihasilkan adalah 12,9 gram dari 100 gram serbuk daun mahkota dewa yang diekstraksi. Proses pengawetan buah tomat dengan menggunakan ekstrak daun mahkota dewa memperoleh hasil yang berbeda-beda. Ekstrak 2\% dapat mengawetkan tomat hingga 7 hari (1 hari lebih lama dari kontrol), sedangkan ekstrak 4\% dan $6 \%$ dapat mengawetkan tomat selama 9 hari (3 hari lebih lama dari kontrol). Setelah dilakukan analisis kadar vitamin $\mathrm{C}$ sebelum dan sesudah pengawetan, diperoleh data seperti yang tertera pada Tabel 1.

Tabel 1. Hasil Analisis Kadar Vitamin C pada Buah Tomat (per $100 \mathrm{~g}$ bahan)

\begin{tabular}{ccc}
\hline Keadaan Buah Tomat & Lama Penyimpanan (hari) & Kadar Vitamin C (mg) \\
\hline Secelum Pengawetan & 0 & 33,440 \\
Penvimpanan Optimal & 9 & 27,580 \\
\hline
\end{tabular}

Penelitian mengenai pemanfaatan ekstrak daun mahkota dewa (Phaleria macrocarpa (Scheff.) Boerl.) sebagai pengawet tomat dilakukan untuk membuktikan bahwa ekstrak daun mahkota dewa memiliki efek antibakteri dalam menghambat pembusukan buah tomat sayur. Daun mahkota dewa yang digunakan adalah daun yang masih segar. Daun ini terlebih dahulu dikeringkan selama 15 hari. Proses pengeringan ini bertujuan untuk menghilangkan kadar air yang terkandung pada daun tersebut. Selanjutnya, daun dihaluskan dengan menggunakan blender dengan tujuan untuk mempercepat proses maserasi. Ketika daun mahkota dewa dihaluskan, maka akan memperluas permukaannya sehingga simplisia dapat lebih banyak berkontak langsung dengan pelarut metanol dan pelarut akan dapat dengan sempurna berdifusi ke dalam molekul-molekul senyawa daun mahkota dewa (Beatrice, 2010).

Senyawa aktif mahkota dewa yang berkhasiat sebagai antibakteri adalah saponin. Pembuktian adanya senyawa aktif tersebut di dalam daun mahkota dewa, maka dilakukan uji pendahuluan saponin terhadap serbuk daun mahkota dewa. Serbuk daun mahkota positif mengandung saponin, hal ini terbukti dengan terbentuknya busa setinggi $1 \mathrm{~cm}$ yang dapat bertahan selama 30 detik. Ketika diteteskan larutan $\mathrm{HCl} 2 \mathrm{~N}$, busa tersebut bertahan lebih lama. Langkah selanjutnya adalah proses ekstraksi 100 gram serbuk daun mahkota dewa dengan metode maserasi menggunakan $600 \mathrm{~mL}$ metanol selama $3 \times 24 \mathrm{jam}$. Metode ekstraksi yang dipilih adalah maserasi, karena pelaksanaannya sederhana serta untuk mengurangi kemungkinan terjadinya penguraian zat aktif yang terkandung dalam daun mahkota dewa oleh pengaruh suhu, karena dalam maserasi tidak ada proses pemanasan. Tujuan maserasi adalah untuk memberi kesempatan pada simplisia berdifusi ke dalam pelarut (Artayanti, 2014).

Setelah dimaserasi, selanjutnya ekstrak dikentalkan dengan menggunakan rotary evaporator pada suhu $50^{\circ} \mathrm{C}$ dan kecepatan 8 rpm hingga tidak terjadi pengembunan lagi. Dari proses ini, diperoleh ekstrak kental sebanyak 12,9 gram. Selanjutnya, dilakukan uji busa saponin untuk memastikan bahwa di dalam ekstrak kental daun mahkota dewa terkandung senyawa saponin yang nantinya kan dimanfaatkan sebagai pengawet tomat. Kemudian membuat ekstrak daun mahkota dewa dengan konsentrasi $0 \%, 2 \%, 4 \%$, dan $6 \%$ masing-masing sebanyak $100 \mathrm{~mL}$. Hal ini bertujuan untuk menentukan konsentrasi ekstrak daun mahkota dewa yang paling efektif untuk digunakan sebagai pengawet alami tomat.

Umumnya kerusakan makanan disebabkan oleh pertumbuhan mikroorganisme terutama oleh bakteri dan jamur. Seperti makhluk hidup lain, mikroorganisme membutuhkan nutrient seperti karbohidrat, protein, lemak, mineral. Mikroorganisme mengubah nutrien menjadi energi yang digunakan untuk pertumbuhan 
mikroorganisme. Pengawetan makanan adalah suatu tindakan yang digunakan oleh manusia pada bahan pangan, sehingga bahan tersebut tidak mudah rusak. Pengawetan dapat menghambat pembusukan, karena lambat laun bahan yang diawetkan akan mengalami kerusakan. Bahan yang telah diawetkan dapat mengalami perubahan tetapi kadang-kadang tidak terlihat langsung karena terjadinya sangat lambat, sehingga bahan pangan akan bermutu baik selama jangka waktu tertentu (Muarfah, 2008).

Proses pengawetan buah tomat dilakukan dengan cara mencelupkan buah tomat ke dalam larutan ekstrak 0\%, 2\%, 4\%, dan 6\% selama 5 detik. Dengan pencelupan ini, maka ekstrak daun mahkota dewa dapat melapisi kulit luar buah tomat. Proses pencelupan tidak boleh terlalu lama, karena akan menyebabkan ekstrak masuk ke bagian dalam buah tomat yang nantinya akan mempengaruhi rasa dari buah tersebut. Setelah dicelupkan, buah tomat dibiarkan selama beberapa hari dan diamati perubahannya setiap hari. Buah tomat yang diawetkan dengan ekstrak daun mahkota dewa $2 \%$ memiliki masa simpan selama 7 hari, lebih lama 1 hari dibandingkan dengan kontrol. Sedangkan ekstrak daun mahkota dewa $4 \%$ dan $6 \%$ dapat mengawetkan tomat selama 9 hari, 3 hari lebih lama dibanding kontrol. Hal ini membuktikan bahwa ekstrak daun mahkota dewa dapat menghambat laju pembusukan buah tomat. Buah yang masak sangat rentan terhadap serangan mikroorganisme. Ekstrak daun mahkota dewa dapat berperan sebagai pengawet alami karena dapat bekerja sebagai antimikroba yang akan merusak membran sitoplasma (Gotawa, dkk., 1999).

Hasil pengawetan dengan ekstrak daun mahkota dewa menunjukkan bahwa semakin lama buah tomat tersebut disimpan, maka akan terjadi perubahan tekstur menjadi lembek dan berair. Perubahan ini disebabkan oleh penguraian zat-zat organik yang terkandung dalam buah tomat pada proses metabolisme. Senyawa organik yang bobot molekulnya besar terurai menjadi senyawa yang berbobot molekul rendah (Muarfah, 2008).

Terjadi perbedaan pada tekstur buah tomat yang diawetkan. Perbedaan tersebut terlihat pada hari ke-1, dimana kontrol telah menjadi lembek sedangkan tomat yang diawetkan masih bertekstur keras walaupun buah sudah masak. Protopektin yang terdapat pada dinding sel buah tomat belum terurai menjadi senyawa pektin yang larut, sehingga buah tomat tidak menjadi lembek. Ekstrak daun mahkota dewa dapat melapisi kulit buah tomat sehingga dapat mepertahankan tingkat kesegarannya. Tingkat kesegaran buah dipengaruhi oleh kandungan air buah tersebut. Buah mengalami kehilangan air pada saat transpirasi, sehingga buah menjadi tidak segar dan kulit buah menjadi keriput (Muarfah, 2008).

Penyakit busuk asam merupakan suatu penyakit penting pada buah tomat yang sudah masak atau matang. Penyakit tersebut apabila tak dikendalikan dapat menyebabkan kerugian kualitas buah yang serius. Busuk asam ini disebabkan oleh jamur Geotrichum candidum. Setiap hari buah tomat mempunyai aroma yang berbeda-beda untuk setiap konsentrasi, mulai dari agak bau asam, bau asam, hingga sangat bau asam. Penyakit busuk asam pada buah tomat biasanya menunjukkan gejala pucat, sangat lunak, pembusukan yang berair pada buah matang dan di penyimpanan, buah yang terserang terdapat spora-spora yang menempel di permukaan buah dan mengeluarkan bau yang tidak sedap atau tengik (Nurhayati, dkk., 2014).

Buahtomatberubahdariwarnakuning-merah menjadi merah seiring lama waktu pengawetan. Tomat merupakan sumberutamalikopen, neurosporene, gamma-karoten, phytoene, danphytofluene(Giovannucci, dkk., 2002). Likopen ialah suatu karotenoid pigmen merah terang yang banyak ditemukan dalam buah tomat dan buah-buahan lain yang berwarna merah merupakan salah satu antioksidan yang sangat kuat. Selain sebagai anti skin aging, lycopene juga memiliki manfaat untuk mencegah penyakit cardiovascular(Rizqy, 2011).

Komposisi kimia buah tomat yang cukup besar adalah vitamin C. Struktur vitamin C

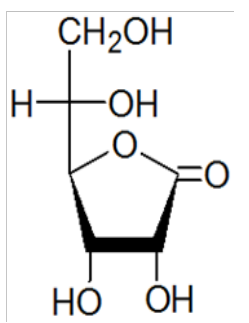

Gambar 2. Struktur Vitamin C

tertera pada Gambar 2.

Kandungan asam askorbat tertinggi pada buah tomat ialah selama proses pembentukan atau pertumbuhannya di pohon dan akan menurun selama pematangan atau penyimpanan, hal ini berkaitan dengan respirasi buah. Selama penyimpanan asam 
askorbat mudah terdegradasi karena pengaruh suhu, konsentrasi gula, pH, oksigen, enzim, katalisis logam, konsentrasi asam askorbat, serta perbandingan asam askorbat dan asam dehidroaskorbat. Penurunan kandungan asam askorbat ini dapat menyebabkan kualitas buah tomat tersebut turun (Muchtadi, dkk., 1993).

Buah tomat pada penyimpanan optimal yaitu ekstrak 6\% selama 9 hari mengalami penurunan kadar vitamin C yaitu dari 33,440 $\mathrm{mg} / 100 \mathrm{~g}$ bahan menjadi $27,580 \mathrm{mg} / 100 \mathrm{~g}$ bahan. Penurunan kadar vitamin $\mathrm{C}$ akan terjadi pada buah yang diawetkan dengan konsentrasi berapapun. Buah tomat yang belum masak memiliki kadar vitamin $\mathrm{C}$ yang lebih besar. Kadar vitamin $\mathrm{C}$ akan menurun seiring tingkat kematangan buah karena mengalami proses metabolisme. Vitamin C sangat peka terhadap oksidasi jika tidak ditangani dengan hati-hati. Asam askorbat akan berkurang karena sangat peka terhadap oksidasi oleh adanya asam askorbat oksidase yang terdapat pada jaringan tanaman (Apandi, 1984).

\section{Kesimpulan}

Ekstrak daun mahkota dewa dapat digunakan sebagai pengawet alami pada buah tomat, karena dapat melapisi kulit buah tomat dan membuat tekstur tomat menjadi lebih keras serta aromanya tidak masam dalam waktu yang lebih lama dari kontrol. Pengawetan buah tomat dengan menggunakan ekstrak daun mahkota dewa dengan konsentrasi 6\% dapat mempertahankan buah tomat hingga 9 hari.

\section{Ucapan Terima Kasih}

Penulis mengucapkan terima kasih kepada kepala laboran laboratorium Agroteknologi FAPERTA dan semua pihak yang telah membantu dalam pelaksanaan penelitian ini.

\section{Referensi}

Adawiyah, R., Soekarto., \& Jenie, B. (1998). Ekstraksi komponen antimikrobia dari biji buah atung. Prosiding Seminar Nasional Teknologi Pangan dan Gizi, Yogyakarta.

Adelaku, O.(2014). Postharvestlosses reduction of tomatoes (lycopersicon esculentum 1) stored in natural preservatives. Asian Journal of Agricultural and Food Sciences, 2(5), 420424.

Apandi, M. (1984). Teknologi buah dan sayur. Bandung: Alumni.

Artayanti, P. (2014). Efektivitas antibakteri ekstrak buah mahkota dewa (phaleria macrocarpa [scheff.] boerl) sebagai bahan alternatif sterilisasi saluran akar gigi terhadap bakteri mix saluran akar gigi. (Skripsi), Universitas Mahasaraswati Denpasar.

Barus, P. (2009). Pemanfaatan bahan pengawet dan antiokidan alami pada industri bahan makanan. (Pidato Pengukuhan Jabatan Guru Besar Tetap dalam Bidang Ilmu Kimia Analitik pada Fakultas Matematika dan Ilmu Pengetahuan Alam, diucapkan dihadapan Rapat Terbuka), Universitas Sumatera Utara, Medan.

Beatrice, L. (2010). Daya antibakteri ekstrak buah mahkota dewa (phaleria macrocarpa scheff (boerl.)) terhadap enterococcus faecalis sebagai bahan medikamen saluran akar secara in vitro. (Skripsi), Universitas Sumatera Utara Medan.

Giovannucci, E., Rimm, E., Liu, Y., Stampfer, M., \& Willett, W. (2002). A prospective study of tomato products, lycopene, and prostate cancer risk. Journal of the National Cancer Institute, 94(5), 391-398.

Gotawa, I., Sugiarto, S., Nurhadi, M., Widiyastuti, Y., Wahyono, S., \& Prapti, I. (1999). Inventaris tanaman obat indonesia jilid V. Jakarta: Departemen Kes. Badan Penelitian dan Pengembangan Kesehatan.

Hudaya, T., Prasetyo, S., \& Kristijarti, A. (2013). Ekstraksi, isolasi, dan uji keaktifan senyawa aktif buah mahkota dewa (phaleria macrocarpa) sebagai pengawet makanan alami. (Laporan Penelitian Lembaga Penelitian dan Pengabdian kepada Masyarakat), Universitas Katolik Parahyangan.

Koswara, S. (2009). Pengawetalamiuntukproduk dan bahan pangan. Diunduh Kembali dari http://tekpan.unimus.ac.id/wp-content/ uploads/2013/07/PENGAWET-ALAMIUNTUK-PRODUK-DAN-BAHANPANGAN.pdf

Muarfah, S. (2008). Isolasi kitosan pada limbah udang dan aplikasinya pada pengawetan buah tomat dan jeruk manis. (Skripsi), Universitas Tadulako.

Muchtadi, D., Palupi, N. S., \& Astawan, M. (1993). Metabolisme zat gizi, jilid II. Jakarta: 
Pustaka Sinar Harapan.

Nurhayati, Suparman, \& Lestari, Y. (2014). Penggunaan sinar ultra violet untuk menekan penyakit busuk asam pada buah tomat pasca panen. Diunduh Kembali dari http://eprints. unsri.ac.id/4632/2/PENGGUNAAN SINAR_ULTRA_VIOLET_UNTUK_MENEKAN_BUSUK_ASAM_TOMAT_PDF.pdf

Pristiadi. (2012). Kajian komparatif aktivitas antioksidan formula pengawet alami ekstrak kecombrang (nicolaia speciosa horan) dan pola pemisahan kromatografis ekstrak bagian-bagian tanaman kecombrang. Journal of Inovation and Technology of Agroindustry, 1(1), 1-12.

Purwadi, A., Usada, W., \& Isyuniarto. (2007). Pengaruh lama waktu ozonisasi terhadap umur simpan buah tomat (lycopersicum esculentum mill). Prosiding PPI-PDIPTN Pustek Akselerator dan Proses Bahan-BATAN Yogyakarta.
Rizqy, A. (2011). Analisa kadar likopen pada buah tomat dengan menggunakan spektrofotometer. (Tugas Akhir), Universitas Diponegoro Semarang.

Suharto, M., Edy, H., \& Dumanauw., J. (2012). Isolasi dan identifikasi senyawa saponin dari ekstrak metanol batang pisang ambon (musa paradisiaca var. sapientum. l). Diunduh Kembali dari http://ejournal. unsrat.ac.id/index.php/pharmacon/article/ view/914/727

Susilawati., Matsjeh, S., Pranowo, H., \& Anwar, C. (2011). Antioxidant activity of 2,6,4'-trihydroxy-4-methoxy benzophenone from ethyl acetate extract of leaves of mahkota dewa (phaleria macrocarpa (scheff.) boerl.). Indo. J. Chem, 11(2), 180185.

Trisnawati, Y., Setiawan., \& Iwan, A. (2003). Tomat pembudidayaan secara komersial. Jakarta: Penebar Swadaya. 